\title{
CHANGES IN THE FLORISTIC COMPOSITION OF A TERRA FIRME RAIN FOREST IN BRAZILIAN AMAZONIA OVER AN EIGHT-YEAR PERIOD IN RESPONSE TO LOGGING. ${ }^{1}$
}

\author{
João Olegário Pereira de CARVALHO²
}

\begin{abstract}
Changes in the floristic composition over an eight-year period in a logged area at the Tapajós National Forest in Brazilian Amazonia are discussed. Two treatments of different intensities of logging were compared with an undisturbed (control) forest. Data were collected from permanent sample-plots. The effects of logging on floristic composition were stronger in the more heavily logged treatment. The number of species decreased immediately after logging, but started to increase before the fifth year after logging and was higher at the end of the study period than before logging. The more heavily logged plots responded more to disturbances, as judged by the increase in the number of species during the period after logging. This forest appears to recover its initial floristic composition after disturbance without intervention.
\end{abstract}

Key-words: Amazonian forest, floristic composition, forest dynamics, logging, Tapajós Forest.

Mudanças na Composição Florística de Uma Floresta Chuvosa de Terra Firme na Amazônia Brasileira durante Um Período de Oito Anos em Resposta à Exploração Mecanizada.

RESUMO - São discutidas as mudanças na composição florística de uma área na Floresta Nacional do Tapajós, na Amazônia brasileira, no período de oito anos. Foram estudadas duas intensidades de exploração e comparadas com uma floresta não-explorada. Os dados foram coletados em parcelas permanentes. Maiores mudanças ocorreram no tratamento com a intensidade de exploração mais pesada. $\mathrm{O}$ número de espécies decresceu imediatamente após a exploraçào, porem começou a crescer cinco anos depois e foi maior no final do periodo estudado do que antes da exploração. As parcelas onde a exploração foi mais pesada responderam melhor aos distúrbios, a julgar pelo aumento no número de espécies durante o periodo pós-exploratório. A floresta parece ser capaz de recuperar natural e rapidamente sua composição florística inicial.

Palavras-chave: Floresta amazônica, composição floristica, dinâmica da floresta, exploração florestal, Floresta do Tapajós.

\section{Introduction}

Floristic composition is one of the first aspects to be analyzed in all forest areas, which are the subject of ecological research, silvicultural management, or any other use. It is essential to study the floristic composition in order to evaluate the forest structure, species diversity, spatial distributions of species, species dynamics and the growth rates of species. The work reported here is such a basis for the ecological and silvicultural research being conducted by Embrapa (Brazilian Agricultural Research Corporation) in a 180 ha area at the Tapajós $\mathrm{Na}$ tional Forest in Brazilian Amazonia.

Some studies already carried out in the area are described in Carvalho

'This paper is part of the "Forest Structure Project" (08.2000.024), Embrapa Amazônia Oriental ${ }^{2}$ Forest Researher, Ph.D., Embrapa Amazônia Oriental, Caixa Postal 48, Belém, PA, Brazil, CEP 66.017-930.E-mail: olegario@cpatu.embrapa.br 
(1992). These include: a sampling of trees $\geq 5 \mathrm{~cm}$ dbh to determine the basal area $\mathrm{ha}^{-1}$, an inventory of trees $15-45 \mathrm{~cm}$ dbh to provide information about the potential stocking for the future, and a pre-logging inventory of trees $\geq 45 \mathrm{~cm}$ dbh (Silva et al., 1985); a study on sociability of commercial species by Lopes et al. (1986); a commercial logging trial and a study on the reduction of basal area at the two intensities of logging according to the treatments of the present study (Carvalho et al., 1986); and a preliminary study of costs and production of logging operations (Costa \& Lopes, 1982). Further information about research undertaken in the study area are found in Carvalho (1984; 1992), Carvalho et al. $(1984,1993)$ and Lopes (1993). The present paper is part of a series of papers dealing with phytosociology and dynamics of the Tapajós National Forest. Changes in floristic composition over an eight-year period in the logged area, as well as in the undisturbed forest, are discussed.

\section{Material and Methods The study area}

The study area lies in the Tapajós National Forest near kilometer 114 of the Santarém-Cuiabá Road (BR 163) in the municipality of Belterra, State of Pará, Brazil. The Tapajós National Forest area is about 600,000 ha at an altitude $c .175 \mathrm{~m}$ above the sea level. Its latitude is $2^{\circ} 40^{\prime}-4^{\circ} 10^{\prime} \mathrm{S}$ and longitude is $54^{\circ} 45^{\prime}-55^{\circ} 30^{\prime} \mathrm{W}$. The climate is classified by Köppen as Ami, which is tropical with one dry season of 2-3 months and an annual rainfall of over $2000 \mathrm{~mm}$. Mean annual air temperature is $c .25^{\circ} \mathrm{C}$, range $18.4-32.6^{\circ} \mathrm{C}$; a mean relative humidity of $86 \%$ (76$93 \%$ ); a mean annual rainfall of 2110 $\mathrm{mm}$ with high rainfall from March to May, and low rainfall from August to November (Carvalho 1982).

The topography is mostly level or slightly rolling. Soil is alic to moderate yellow latosol with heavy clay texture (60-94\% of clay), with inclusion of concretionary yellow latosol, derived from clay stone (Brasil-FUPEF 1986). Following the general pattern for the soils of terra firme Amazonian forests it is low in nutrients. Dubois (1976) classified the forest type as zonal primary high terra firme forest without babaçu palm (Orbignya barbosiana Burret).

This area was selected because it represents the majority of the terra firme dense forests in the region. It is also sufficiently remote from any private settlement to be disturbed by the cutting of trees for building materials or fuel. Apparently the only disturbances in the area were due to hunting of animals for food, collecting edible fruits, tapping of some Hevea brasiliensis (HBK) Muell. Arg. trees, and barking trees of medicinal species such as Aniba canelilla (Kunth) Mez, Tabebuia serratifolia (VahI) Nicholson and Stryphnodendron adstringens Mart. Those activities probably did not cause any serious damage or alter the structure and composition of the forest significantly.

\section{Methods}

The research was initiated in 1981 by obtaining a $100 \%$ pre-felling forest inventory of trees $\geq 45 \mathrm{~cm} \mathrm{dbh}$ over a total area of 144 ha. That year 
climber cutting was undertaken and the permanent sample plots were established and measured for the first time within the 144 ha. In 1982 the area was logged. The subsequent measurements took place in 1983 - one year after logging, 1987 - five years after logging and in 1989 - seven years after logging. A 36 ha control with permanent plots was established in 1983. It was first measured then and later in 1987 and 1989. The total study area was thus 180 ha.

The experiment was initially designed with four treatments ( $\mathrm{T} 1, \mathrm{~T} 2$, $\mathrm{T} 3, \mathrm{~T} 4)$ combining intensities of logging and silvicultural treatments, and a control area (T0). Silvicultural treatments T3 and T4 were not, in fact, applied, because the Brazilian Government did not permit the use of any chemical products in natural forests in the 1980s. Therefore, in the present study, only $\mathrm{T} 1, \mathrm{~T} 2$ and T0, totaling 108 ha (36 ha for each treatment and control) are analyzed and discussed.

The forest structure was similar in both the T1 and T2 areas before logging and in the control block (Carvalho, 1992). The Embrapa research team carried out logging. Powersaws were used for cutting. An attempt was made at directional felling and a wheeled skidder was used, operating in trails previously opened by a bulldozer. Particulars of each treatment are as follows:

$\mathrm{T} 1$ - this treatment consisted of cutting trees of 38 commercial species $\geq 45 \mathrm{~cm} \mathrm{dbh}$. This dbh limit was applied because it is the minimum permitted by the Brazilian Forest Law for felling trees in natural forests. The 38 commercial species were selected from a list of traded species in the regional timber market and were based on their abundance, basal area and timber volume recorded in a previous forest inventory carried out in the study area (Silva et al., 1985).

T2 - cutting of trees of the same 38 commercial species as in $\mathrm{T} 1$ but $\geq$ $55 \mathrm{~cm} \mathrm{dbh}$. This diameter limit was applied because generally the sawmills in the Tapajós region are set to use logs $\geq$ $45 \mathrm{~cm}$ diameter. The top diameter of a bole might only measure $45 \mathrm{~cm}$ if its dbh is at least $50 \mathrm{~cm}$, although this varies from one species to another. The decision to take $55 \mathrm{~cm}$ as the cutting limit assumed that all trees felled would have a diameter greater than $45 \mathrm{~cm}$ at any part of their bole. This does not allow for any loss of timber, which occurs, with trees of $45 \mathrm{~cm} \mathrm{dbh}$, which is the traditional cutting limit in Amazonia.

$\mathrm{T} 0$ - the control area remained in its natural untreated condition.

The statistical design of the treatments constituted four randomized blocks. Each treatment (T1 to T4) was thus replicated four times, with one 9 ha treatment plot per block. The control was a separate block also divided into four plots, each of 9 ha. Each plot was sub-divided into nine 1 ha quadrats. Three of which were selected at random. A $50 \mathrm{~m} \times 50 \mathrm{~m}$ permanent sample-plot was set in the center of each. Following the procedure of Silva \& Lopes (1984), each permanent sample-plot was further divided into 25 subsample-plots of $10 \mathrm{~m} \times 10 \mathrm{~m}$ and marked with permanent top-redpainted stakes. All individuals $\geq 5 \mathrm{~cm}$ 
$\mathrm{dbh}$ were number-tagged, identified and measured. In total, each treatment was applied over 36 ha, and included 3 ha of measured sample-plots.

The guidelines proposed by Synnott (1979) and Whitmore (1989b) for the measurement of the permanent sample-plots in tropical rain forests were followed. Further procedures in measurement were based up on Hutchinson (1982) and Silva \& Lopes (1984), described also in Silva (1989)

Individual trees were identified by their vernacular names in the forest. Botanical specimens were collected from less common trees for later identification in the Embrapa Herbarium. Whenever possible, identification was made to the species level (Carvalho, 1992). Species were classified by their wood quality group and ecological class. The wood quality groups were: commercial - species presently sold in the national or international market; potential species likely to be sold in the near future, mainly on account of their wood properties; non-commercial - species not marketable and without potential, or species whose wood is not yet sufficiently known. This classification was based on the characteristics and uses of wood, the timber market in Brazil and export, according to Brasil-IBDF (1980; 1981; 1988), Brasil-SUDAM (1981), Silva (1989) and Teixeira et al. (1988).

The species were further classified as light-demanding or shade-tolerant species, based on the requirement of their seedlings for solar radiation observed casually in the field during the study period (Carvalho, 1992), and according to distinguishing character suggested by Swaine \& Whitmore (1988) and Whitmore (1989a; 1990).

The total number of species, genera and families were determined for $\mathrm{T} 1$ and $\mathrm{T} 2$ on four occasions and for the unlogged (control) area on three occasions. The numbers of species were also calculated on a per plot basis in order to permit statistical comparison. The family importance values (FIV) were obtained, according to Mori et al. (1983), by the sum of family relative values from abundance, dominance and number of species per family (FIV= FRA + FRD + FRN, where FRA is the family relative abundance, FRD is the family relative dominance, and FRN is the relative number of species per family). FRA is the percentage of the number of trees ha ${ }^{-1}$ of a certain family in relation to the total number of individuals (FRA $=$ [number of trees of a family $\mathrm{ha}^{-1}$ / total number of trees ha-1] $\mathrm{x}$ 100). FRD is the percentage of basal area of a certain family in relation to the total basal area of the population (FRD $=[$ basal area of a family / total basal area] x 100). FRN is the percentage of the number of species of a certain family in relation to the total number of species (FRN = [number of species of a family / total number of species] x 100).

Analyses of variance were used to compare the treatments $\mathrm{T} 1$ and $\mathrm{T} 2$, and logged and unlogged forests. Initially, two-way analyses of variance were performed, as a randomized block design. Since there were no significant differences between the blocks $(p>0.05)$, one-way analyses of variance were applied in each case. 


\section{Results}

In the 36 permanent sample-plots (totally 9 ha area) 10,926 individuals $\geq$ $5 \mathrm{~cm}$ dbh were recorded. These individuals were the trees standing before logging plus ingrowths to $>5 \mathrm{~cm}$ class during the period of studies. Of the total number $83 \%$ were identified to the species level, $16.5 \%$ to the genus only and $0.5 \%$ remained undetermined. There were 257 species in 151 genera from 49 families identified during the study period. Table 1 shows the number of families, genera and species found in the study area. Table 2 shows the changes in number of species over the study period.

Since this study is only concerned with trees $\geq 5 \mathrm{~cm}$ dbh, the word "appearance of species" in the results and discussion means the ingrowth of trees into the lowest diameter class. Although individuals of some pioneer species would be able to grow from seed to a tree of $5.0 \mathrm{~cm} \mathrm{dbh}$, from one measurement to another, most of the appearance and increases in numbers of species are due to growth of small trees that already existed. Also disappearance or loss of species means the death of trees $\geq 5.0 \mathrm{~cm}$ dbh only.

Analysis of variance, taking into account the mean number of species per plot, showed no significant difference between T1 and T2 during the eight-year study period $(\mathrm{p}<0.05)$, but both treatments were significantly different from the unlogged forest $(\mathrm{p}<0.05)$, except at the last time of measurement.

In $T 1$ (logging of trees $\geq 45 \mathrm{~cm}$ dbh) a new family (Vochysiaceae) appeared one year after logging (1983) but the number of species decreased. The species which disappeared a year after logging were Ambelania acida Aubl., Bagassa guianensis Aubl., Bertholletia excelsa HBK, Brosimum discolor Schott, Cecropia leucoma Miquel, Dipteryx odorata (Aubl.) Willd., Eperua stipulata Klein., Ocotea canaliculata Mez, Parkia pendula Benth., Phyllanthus nobilis Muell. Arg., Saccoglottis guianensis Benth. and Vatairea guianensis Aubl. On the other hand four new species appeared: Clarisia racemosa Ruiz. et

Table 1. Numbers of families (NF), genera (NG) and species (NS) of trees $\geq 5 \mathrm{~cm}$ dbh in 9 ha sampled at the Tapajós National Forest in Brazilian Amazonia before (1981) and after logging. $\mathrm{T} 1=$ logging of trees $\geq 45 \mathrm{~cm} \mathrm{dbh}, \mathrm{T} 2=$ logging of trees $\geq 55 \mathrm{~cm} \mathrm{dbh}$.

\begin{tabular}{|c|c|c|c|c|c|c|c|c|c|}
\hline \multirow{3}{*}{ Year } & \multicolumn{5}{|c|}{ Logged Forest } & & \multirow{2}{*}{\multicolumn{3}{|c|}{$\begin{array}{l}\text { Unlogged Forest } \\
\text { T0 }\end{array}$}} \\
\hline & \multicolumn{3}{|c|}{$\mathrm{T1}$} & \multicolumn{3}{|c|}{$\mathrm{T} 2$} & & & \\
\hline & NF & NG & NS & NF & $N G$ & NS & NF & NG & NS \\
\hline 1981 & 45 & 128 & 211 & 45 & 133 & 217 & 2 & - & - \\
\hline 1983 & 46 & 126 & 203 & 46 & 129 & 213 & 48 & 137 & 226 \\
\hline 1987 & 48 & 134 & 215 & 47 & 133 & 222 & 47 & 135 & 226 \\
\hline 1989 & 48 & 137 & 221 & 47 & 135 & 225 & 46 & 133 & 219 \\
\hline
\end{tabular}


Table 2. Numbers of species of trees $\geq 5 \mathrm{~cm}$ dbh over an 8-year period (1981-1989) in 9 ha sampled at the Tapajós National Forest in Brazilian Amazonia. T1 $=\operatorname{logging}$ of trees $\geq 45 \mathrm{~cm}$ $\mathrm{dbh}, \mathrm{T} 2=$ logging of trees $\geq 55 \mathrm{~cm}$ dbh, T0 = unlogged area. T1 and T2 were logged in 1982 . The number of species are per treatment sample ( $3 \mathrm{ha})$; the number of species in T1+T2 refers to the sum of sample plots ( $6 \mathrm{ha})$ in the logged forest; the number of species in $\mathrm{T} 1+\mathrm{T} 2+\mathrm{T} 0$ is the total number recorded in the whole sample area ( 9 ha). T0 was not recorded in 1981.

\begin{tabular}{ccccc}
\hline Treatment & 1981 & 1983 & 1987 & 1989 \\
\cline { 2 - 5 } & \multicolumn{4}{c}{ Numbers of species } \\
\hline T0 & 226 & 226 & 219 \\
T1 & 211 & 203 & 215 & 221 \\
T2 & 217 & 213 & 222 & 225 \\
T1+T2 & 236 & 228 & 234 & 240 \\
T1+T2+T0 & 236 & 251 & 254 & 257 \\
\hline
\end{tabular}

Pav., Jacaranda copaia (Aubl.) D.Don, Sextonia rubra (Mez) van der Werff and Vochysia surinamensis Stafl. Five years after logging (1987) two new families (Monimiaceae and Chrysobalanaceae) appeared and the numbers of species increased. The new species were: Aegiphila sp., Ambelania grandiflora Huber, $\mathrm{Ce}$ cropia sciadophylla Mart, Dimorphandra gardneriana Jul., Ficus insipida Willd., Parinari barbatum Ducke, Pithecellobium sp., Protium puncticulatum Macbride, Siparuna dicipiens A.DC. and Vismia japurensis Reichardt. The species Eperua stipulata and Phyllanthus nobilis, that were not found immediately after logging (1983), reappeared five years later (1987). No species was lost on this occasion. New changes occurred seven years after logging (1989). Bagassa guianensis and Brosimum discolor, which disappeared immediately after logging, reappeared this time. The new species seven years after logging were:
Dinizia excelsa Ducke, Zygia cauliflora (Willd.) Killip ex Record, Sapium marmieri and Xylopia nitida Dunal. This time again no species were lost. The changes of species in $\mathrm{T} 1$ are shown in Table 3.

In T2 (logging of trees $\geq 55 \mathrm{~cm}$ $\mathrm{dbh}$ ) the families Caricaceae and Connaraceae appeared a year after logging but the Araliaceae disappeared. Seven species disappeared after logging (1983): Apuleia molaris Spruce ex Benth., Bellucia grossularioides (L.) Triam, Cariniana micrantha Ducke, Schefflera morototoni (Aubl.) Maguire, Dinizia excelsa, Goupia glabra Ducke and Sapium marmieri Hub. New species this time were Connarus perrottettii (D.C.) Planch., Homalium guianense (Aubl.) O.Ken. and Jacaratia spinosa (Aubl.) DC. Five years after logging (1987) the family Araliaceae reappeared and also the number of species increased. The following new species appeared: Aegiphila sp., Ambelania grandi- 
Table 3. Numbers of species of tree $\geq 5 \mathrm{~cm}$ dbh that appeared or desappeared over a 7-year period (1983-1989) after logging at the Tapajós National Forest in Brazilian Amazonia. T1 = logging of trees $\geq 45 \mathrm{~cm}$ dbh, T2 $=$ logging of trees $\geq 55 \mathrm{~cm}$ dbh, T0 $=$ unlogged forest. $\mathrm{T} 1$ and T2 were logged in 1982.

Table 3a. Species that appeared (new species)

\begin{tabular}{ccccc}
\hline Treatment & 1983 & 1987 & 1989 & $1983-1989$ \\
\hline T0 & 0 & 3 & 3 & 2 \\
T1 & 4 & 14 & 18 & 18 \\
T2 & 3 & 11 & 14 & 14 \\
T1+T2 & 7 & 21 & 26 & 26 \\
\hline
\end{tabular}

Table 3b. Species that desapeared (lost species)

\begin{tabular}{ccccc}
\hline Treatment & 1983 & 1987 & 1989 & $1983-1989$ \\
\hline T0 & 0 & 3 & 6 & 9 \\
T1 & 12 & 12 & 12 & 8 \\
T2 & 7 & 9 & 9 & 6 \\
T1+T2 & 20 & 22 & 22 & 14 \\
\hline
\end{tabular}

Table 3c. Species that appeared and desappeared

\begin{tabular}{ccccc}
\hline Treatment & 1983 & 1987 & 1989 & $1983-1989$ \\
\hline T0 & - & 0 & 1 & 1 \\
T1 & 2 & 4 & 4 \\
T2 & - & 3 & 3 & 3 \\
T1 + T2 & - & 5 & 8 & 8 \\
\hline
\end{tabular}

flora, Capirona huberiana Ducke, Eugenia patrisii Vahl, Protium puncticulatum, Stryphnodendron pulcherrimum (Willd.) Hochr. and Vismia japurensis Reichardt. Species Bellucia grossularioides, Schefflera morototoni and Sapium marmieri, which died a year after logging, reappeared this time. Only Phyllanthus nobilis and Tabebuia impetiginosa Mart. disappeared at this measurement. Seven years after logging (1989) three new species appeared: Joannesia heveoides Ducke, Licaria armeniaca (Nees) Kosterm. and Protium heptaphyllum March. There was no loss of species on this occasion. (Tab. 3).

In the unlogged forest, the number of families was reduced between the first (1983) and the second measurements (1987), but the number of species remained the same. The species Enterolobium sp., Protium sagotianum March. and Sclerolobium paraense Hub. appeared on this occasion, but Apuleia molaris, Parinari barbatum 
and Swartzia corrugata Benth. disappeared. At the end of the study period, the species Annona montana Macfad., Eryotheca globosa (Aubl.) Robins, Schefflera morototoni, Diplotropis purpurea (Rich.) Armsh. and Xylopia nitida disappeared. And Sclerolobium paraense, which appeared at the second measurement, disappeared this time (Tab. 3).

The 20 most important families in terms of floristic composition, according to the Family Importance Value, are shown in Table 4. These families contain the majority of species and individuals, and those of higher basal areas. They are also responsible for almost all the changes in floristic composition over the eight-year period. Most of the species that disappeared, as well as those that reappeared and the new species belong to this families.

Comparing the two intensities of logging in Tapajós, the number of species that disappeared over the study period in T1 ( 8 species) was slightly higher than the corresponding number in the less intense T2 (6 species). Eighteen new species appeared in T1 and fourteen in T2. The numbers of species that disappeared and then reappeared over the period, four in T1 and three in T2, were almost identical. In general the changes in T1, where there was more solar radiation because of the greater intensity of logging, were a little higher than in T2. In addition to the slight differences in changes of species composition that occurred between the two intensities of logging, between logged and unlogged forest, differences were also found within treatments. For example, reduction in numbers of species caused by logging ranged from 3 to 19 species per plot in $\mathrm{T} 1$ and from 0 to 14 species per plot in T2. Corresponding coefficients of variation were $46 \%$ and $48 \%$. In general, the greatest reduction in the number of species occurred in plots were more trees were cut or destroyed by logging, and where high basal areas were reduced.

One plot in $\mathrm{T} 1$, which by chance had no tree cut, showed a reduction of three species due to 36 small individuals destroyed by logging operations. But in $\mathrm{T} 2$, a plot apparently not physically disturbed during exploitation had no lost species. Moreover that same plot in T1 showed an increase of 9 species during the eight-year period, while the one in T2 increased by only two species.

The changes were smaller in the unlogged forest. Although the number of species (nine) that disappeared over the study period was higher than in T1, the number of new species (only two) was $11 \%$ lower than in $\mathrm{T} 1$ and $14 \%$ lower than in T2. One species (Sclerolobium paraense) appeared and disappeared over the period. Analyzing each plot separately, slight differences are evident. For example, some plots gained new species over the study period without any loss and vice versa. No plot kept the same number of species over the entire period. In the unlogged area the range in net number of species was $0-7$. It was observed that natural disturbances such as fall or death of neighboring trees of the measurement plot, generated an increase in amount of solar radiation 
Table 4. Family Importance Value (FIV) of the 20 most important families in 9 ha sampled at the Tapajos National Forest, selected according to numbers of genera and species of trees $\geq 5$ $\mathrm{cm} \mathrm{dbh}$, before logging (1981) and seven years after logging (1989) in the logged area, and for the first (1983) and third (1989) measurements in the unlogged forest. T1 = logging of trees $\geq$ $45 \mathrm{~cm} \mathrm{dbh}, \mathrm{T} 2=$ logging of trees $\geq 55 \mathrm{~cm} \mathrm{dbh}$.

\begin{tabular}{|c|c|c|c|c|c|c|}
\hline \multirow[b]{2}{*}{ Family } & \multicolumn{2}{|c|}{$\mathrm{T} 1$} & \multicolumn{2}{|l|}{ T2 } & \multicolumn{2}{|c|}{ Unlogged Forest } \\
\hline & 1981 & 1989 & 1981 & 1989 & 1981 & 1989 \\
\hline Leguminosae & 42.7 & 51.1 & 50.7 & 51.3 & 53.1 & 49.9 \\
\hline Sapotaceae & 24.9 & 22.1 & 27.1 & 23.1 & 29.4 & 30.4 \\
\hline Lecythidaceae & 26.5 & 21.1 & 26.5 & 19.1 & 22.1 & 23.1 \\
\hline Moraceae & 16.8 & 28.6 & 18.6 & 24.6 & 15.6 & 16.6 \\
\hline Violaceae & 21.2 & 21.2 & 20.2 & 19.2 & 15.6 & 15.6 \\
\hline Burseraceae & 11.9 & 11.3 & 14.9 & 15.1 & 14.3 & 14.7 \\
\hline Annonaceae & 12.3 & 10.7 & 9.7 & 9.7 & 13.7 & 12.9 \\
\hline Lauraceae & 13.4 & 12.4 & 14.8 & 16.2 & 12.4 & 12.4 \\
\hline Apocynaceae & 7.7 & 5.7 & 11.1 & 10.5 & 12.1 & 12.1 \\
\hline Meliaceae & 14.9 & 8.9 & 11.6 & 8.6 & 6.6 & 6.6 \\
\hline Myristicaceae & 6.6 & 6.6 & 6.6 & 5.6 & 6.6 & 6.6 \\
\hline Rubiaceae & 6.3 & 5.3 & 4.9 & 5.3 & 6.3 & 6.3 \\
\hline Myrtaceae & 3.9 & 3.9 & 3.6 & 3.9 & 5.9 & 5.9 \\
\hline Euphorbiaceae & 6.3 & 5.7 & 4,7 & 4.7 & 4.9 & 4.9 \\
\hline Guttiferae & 3.9 & 4.3 & 2.5 & 2.9 & 4.3 & 4.3 \\
\hline Sterculiaceae & 3.2 & 3.2 & 3.2 & 3.2 & 4.2 & 4.2 \\
\hline Anacardiaceae & 2.5 & 2.5 & 3.2 & 2.2 & 3.6 & 3.6 \\
\hline Melastomataceae & 3.3 & 3.3 & 3,3 & 3.3 & 2.9 & 2.9 \\
\hline Flacourtiaceae & 3.6 & 4.6 & 2.5 & 3.9 & 2.5 & 2.5 \\
\hline Olacaceae & 4.4 & 5.4 & 6.4 & 7.4 & 2.4 & 2.4 \\
\hline
\end{tabular}

inside the plot, allowing the appearance of some species and an increase in abundance of others.

Comparing the species themselves, those that disappeared in $\mathrm{T} 1$ were different from those in $\mathrm{T} 2$. Only Phyllanthus nobilis coincided. The species that appeared immediately after logging were different between treatments. Five years after logging four $(17 \%)$ new species were common to both treatments T1 and T2. But again in the following years all species that changed were different between the treatments. In general, most of the species involved in these dynamics in both treatments belong to the group of non-commercial species, according to 
the classification given in Carvalho (1992).

The loss of species in the logged area in Tapajós occurred mainly because of the logging. Of the loss in T1 and $\mathrm{T} 2,38 \%$ and $44 \%$ respectively, were due to commercial species that were cut. Non-commercial species were lost in consequence of the logging operations. Light-demanding species, including the three wood quality groups, in both treatments, represented $55 \%$ of the lost species.

The composition of new species in the logged area was different between the two treatments in some respect, when comparing groups of species. In $\mathrm{T} 1,51 \%$ of the 18 new species were light-demanding against $47 \%$ of 14 new species in T2. But in T1 $23 \%$ were commercial species and $14 \%$ were potential and $64 \%$ were non-commercial species against T2 where $6 \%$ were commercial and $94 \%$ were non-commercial. Apparently the most intense logging (T1) was more favorable to growing young trees of commercial (mainly light-demanding) species during the eight-year period.

In addition, comparing the gain and loss of species between T1 and the unlogged forest, no species coincided. The only co-incidences noted were when the loss of species was compared between $\mathrm{T} 2$ and the unlogged forest. Two species (Apuleia molaris and Schefflera morototoni) disappeared during the study period in both areas.

In the unlogged forest, the loss of species was due to natural causes. Schefflera morototoni and Diplotropis purpurea disappeared when the only two big trees $(>60 \mathrm{~cm}$ $\mathrm{dbh}$ ) fell in storms. The other disappeared through death of individuals $<15$ $\mathrm{cm} \mathrm{dbh}$, probably in consequence of the fall of those large trees. Fifty-six per cent of the lost species were shadetolerant. Of the three new species that came in, two were shade-tolerant. Considering wood quality, two species were non-commercial (Protium sagotianum, Sclerolobium paraense) and one was potentially commercial (Enterolobium sp.).

\section{Discussion}

These changes can be compared with those observed in other tropical forests. Although there are similarities at family level between the tropical rain forests worldwide, the genera and species are almost entirely different, even within each rain forest region (Whitmore, 1990). Differences in floristic composition are also noted between places in the same area at the same time. This was evident in the treatments of the present study and was shown as well in three treatment plots analyzed by Okali \& Ola-Adams (1987) in Omo Forest Reserve, Nigeria. Further evidence of these differences can be found by comparing the studies done by Black et al. (1950), Pires et al. (1953), Costa et al. (1999), Soares \& Carvalho (1999), Lima \& Carvalho (2000) and Sandel \& Carvalho (2000) on six areas in the State of Pará in Brazilian Amazonia. Differences are more evident between distant areas, for example between countries or continents. In a study review on dynamics of 18 tropical sites, 
including America, Africa and Southeast Asia, considering trees $\geq 10 \mathrm{~cm}$ $\mathrm{dbh}$, Swaine et al. (1987b) found a wide variation in number of species, from 52 to $141 \mathrm{ha}^{-1}$.

In 2 ha of moist semi-deciduous forest at Kade, Ghana, Swaine et al. (1987a) identified 120 species from 36 families, over a 14-year period. Seven species disappeared but were replaced by seven new species, representing a turnover of about $1 \%$ annually. They enumerated trees and climbers $\geq 9.5$ $\mathrm{cm} \mathrm{dbh}$. In the present study there were 201 species, considering only trees $\geq 9.5 \mathrm{~cm}$ dbh in a 2 ha sample. This number is higher than that found at Kade, in a time period longer than that in Tapajós.

Probably because eight years is not a long period, the floristic composition was not highly dynamic. In the logged forest, 14 species disappeared over the 8 -year period, but 26 new ones appeared. In the unlogged area, nine species disappeared and only two new ones came in. In the study of Manokaran \& Kochummen (1987) in an unlogged forest in Peninsular Malaysia in a 34-year period, 48 species disappeared and were replaced by another 48; and six species appeared after the beginning of the period and disappeared before the end. In Tapajós seven species disappeared and reappeared during the period. In this Malaysian study the pioneer species, defined according to the classification given by Swaine \& Whitmore (1988) and discussed in Whitmore (1989a, 1990 ), were not very abundant and declined in numbers of species and trees from the beginning to the end of the period. Also in Tapajos, in the unlogged forest, the abundance of pioneer species was very low and remained almost the same during the whole period, varying only by $0.3 \%$ from the beginning to the end. On the other hand, in the logged area, 17 new pioneer species appeared over the study period. The abundance of the majority of the pioneer species increased each year after logging, but this is not a worrying problem because most of them are often short-lived, according to characteristics described by Swaine \& Whitmore (1988), and others are commercial species such as Caryocar villosum (Aubl.) Pers., Cordia alliodora (Ruiz \& Pav.) Oken, Cordia bicolor A.DC and Jacaranda copaia, or potential species such as Bixa arborea Huber, Laetia procera (Poepp. et Endl.) Eichl., Tachigali chrysophylla (Poepp.) Zarucchy \& Herend. and Tachigali myrmecophila (Ducke) Ducke, amongst others. Abundance of species is discussed in detail in Carvalho (1992).

Some ecological characteristics and effects of logging in a rain forest in north Queensland were conducted by Nicholson et al. (1988). They analyzed tree species $\geq 10 \mathrm{~cm}$ dbh in 13 plots of different sizes, under different silvicultural interventions and in different sites. Plot 408 was the largest (1.6 ha) and the richest with 125 species before logging. This number is the same as that found in only 0.25 ha of unlogged forest in Tapajós also considering trees $\geq 10 \mathrm{~cm}$ dbh. Co-incidentally the number of species after log- 
ging in plot 408 in Queensland (117 species) was identical to that recorded one year after the heavier logging in only 0.25 ha in Tapajós. The losses of species in most of the study plots in Queensland were higher than in Tapajós, probably because the logging was also more intense and because the logging reported was not the first cut (Saxon, 1990).

In studies that deal with various plant life forms the numbers of species are markedly higher. For instance, in a 12.4 ha area at La Selva, Costa Rica, Lieberman \& Lieberman (1987) found 269 species in 162 genera and 62 families, considering individuals $\geq 10 \mathrm{~cm}$ $\mathrm{dbh}$. The species measured included; seven palms, twenty lianas, two strangler figs, one tree-fern and 239 true trees. Considering only true trees, the number of species recorded in that study was the same as found in only 6 ha in Tapajós, taking into account trees $\geq 10 \mathrm{~cm} \mathrm{dbh}$.

The present study also indicates once more that the intensity of logging has an important influence on floristic composition, although it is not significant in terms of numbers of species per area. This was noted by Whitmore (1984) in relation to the size of gaps in natural forests: different species are successful in growing up in gaps of different size. Whitmore (1988) further remarked that the species composition in exploited areas depends on what grows up in the gaps created by logging, and that the greater the disturbance the more the light-demanding species are favored. This was noted in two heavily logged areas studied by Enright (1978) in Papua New Guinea, and by Johns (1988) at Sungai Tekam, West Malaysia, where the colonizing tree species, mainly Euphorbiaceae, germinated and grew rapidly immediately after logging, invading all big gaps.

Nicholson et al. (1988) in Queensland, found that logging reduced species numbers among trees $\geq 10 \mathrm{~cm}$ $\mathrm{dbh}$, but they also showed that there was an increase in numbers of species with time after logging. The present study in Tapajós revealed that the number of species was reduced immediately after logging but it increased with time (Tab. 2) and showed more species seven years after logging (1989 - end of the study period) than before (1981). It is not known yet how long the number of species will increase after logging, or when it will start to decline. However it is especially worthy of attention that in the logged forest in Tapajós, considering trees $\geq 5 \mathrm{~cm}$ dbh or trees $\geq 10 \mathrm{~cm}$ $\mathrm{dbh}$, the number of species rose with time and that there were also commercial species among these new ones.

Nicholson et al. (1988) stated that in some virgin rain forests in Queensland there is a decrease in number of species with time, but the reexamination of their data by Saxon (1990) showed that this occurred only in two plots, the largest and the smallest, while in another two, which suffered natural disturbance, it did not happen. Saxon concluded that in presence of natural disturbances species richness and species diversity did not decline in virgin forest. Nicholson et al. (1990) replied that if a natural disturbance is similar to a moderate or 
heavy logging no distinction can be made between natural and artificial disturbance about their response to changes in numbers of species and diversity. In Tapajós there was a loss of $3 \%$ in numbers of species in the unlogged forest over seven years as already discussed (Tabs 2, 3). But due to the short study period this fact gives no evidence that the number of lost species will continue increasing with time. Any loss of large trees and consequent increase of solar radiation could change that tendency in the near future.

To conclude, changes in floristic composition occurred under undisturbed conditions as well as in response to natural or man-made disturbances. The number of species decreased immediately after logging, but started to increase by the fifth year after logging. The more heavily logged plots responded more to disturbance, as judged by the increase in the number of species during the period following logging. It appears that the forest can rapidly recover its initial floristic composition without intervention, agreeing with statements made by Carvalho (1997) on dynamics of natural forests and its implication to the forest management.

\section{Literature cited}

Black, G.A.; Dobzhansky, T.H.; Pavan, C. 1950. Some attempts to estimate species diversity and population density of trees in Amazonia forests. Botanical Gazette, v.111, p.413-425.

Carvalho, J.O.P. de. 1982. Análise estrutural da regeneração natural em floresta tropical densa na região do Tapajós no Estado do Pará. Curitiba: UFPR. $129 \mathrm{p}$. Dissertação Mestrado.
Carvalho, J.O.P. de. 1984. Manejo de regeneração natural de espécies florestais. Belém: EMBRAPA-CPATU. 22p. (EMBRAPA-CPATU. Documentos, 34).

Carvalho, J.O.P. de. 1987. Subsidios para o manejo de florestas naturais na Amazônia brasileira: resultados da pesquisa da Embrapa/IBDF-PNPF, Belém: EMBRAPA - CPATU. 35p. (EMBRAPA - CPATU. Documentos, 43).

Carvalho, J.O.P. de. 1992. Structure and dynamics of a logged over Brazilian Amazonian rain forest. Oxford: University of Oxford. 215p. D.Phil. Thesis.

Carvalho, J.O.P. de. 1997. Dinâmica de florestas naturais e sua implicação para o manejo florestal. Curitiba: EMBRAPACNPF. p43-55. (EMBRAPA-CNPF. Documentos, 34).

Carvalho, J.O.P. de; Silva, J.N.M.; Lopes, J. do C.A. 1993. Spatial distribution of tree species of a terra firme rain forest in Brazilian Amazon. In: Congresso Florestal Panamericano, 1.; Congresso Florestal Brasileiro, 7. 1993, Curitiba, PR. Floresta para o desenvolvimento: política, ambiente, tecnologia e mercado - anais. Curitiba: SBS/SBEF. v.1, p.393-396.

Carvalho, J.O.P. de; Silva, J.N.M.; Lopes, J. do C.A.; Jimmenez Valcarcel, V.M.; Graaf, N.R. de. 1986. Redução da densidade de uma floresta tropical úmida densa devido à exploração mecanizada. In: Symposium of the Humid Tropics, 1., 1984 , Belém,PA. Proceedings. Belém: EMBRAPA-CPATU. v.2, p.269-281. (EMBRAPA-CPATU, Documentos, 36).

Carvalho, J.O.P. de; Silva, J.N.M.; Lopes, J.do C.A.; Costa, H.B. da. 1984. Manejo de florestas naturais do trópico úmido com referència especial à Floresta Nacional do Tapajós no Estado do Pará. Belém: EMBRAPA-CPATU. 14p. (EMBRAPACPATU. Documentos, 26).

Costa, D.H.M.; Ferreira, C.A.P.; Silva, J.N.M.; Lopes, J. do C.A.; Carvalho; J.O.P. de 1999. Potencial madeireiro de floresta densa no municipio de Moju no Pará. Belém: EMBRAPA-CPATU. p.138-141. 
(EMBRAPA-CPATU. Documentos, 123).

Costa, H.B. da; Lopes, J. do C.A. 1982. Rendimento de derruba e extração mecanizada em florestas de terra firme da Amazônia. In: Congresso Nacional sobre Essências Nativas, 2,, 1982, Campos do Jordão. Anais. São Paulo: Instituto Florestal; Silvicultura em São Paulo, v. 16 A, p.1253-1258,1982.

Dubois, J.C.L. 1976. Preliminary management forest guidelines for the National Forest of Tapajós. Belém: IBDF/PRODEPEF. 42p.

Enright, N. J. 1978. The effects of logging on the regeneration and nutrient budget of a Araucaria cuninghamii dominated tropical rainforest in Papua New Guinea. The Malaysian Forester, v.41, p.303-318.

Fundação de Pesquisas Florestais do Paraná (Curitiba, PR). 1986. Relações entre solos e a vegetação natural em área da Floresta Nacional do Tapajós. Curitiba.

Hutchinson, I.D. 1982. Field enumeration of permanent sample plots in the mixed Dipterocarp forest of Sarawak. [S.1.]: FAO, (FAO, Report FO:MAL/76/008. Field Documents, 16).

Instituto Brasileiro de Desenvolvimento Florestal (IBDF). 1988. Amazonian timbers: characteristics and utilization; CuruáUna Experimental Forest Station. Brasília, 236p.

Instituto Brasileiro de Desenvolvimento Florestal (IBDF).. 1981. Amazonian timbers: characteristics and utilization; Tapajós National Forest. Brasília. 113p.

Instituto Brasileiro de Desenvolvimento Florestal (IBDF).. 1980. Woods from Tucurui: characteristics and application. Brasilia. 49p.

Johns, A.D, 1988. Effects of selective timber extraction on rain forest structure and composition and some consequences for frugivores and folivores. Biotropica, v.20, p.31-37.

Lieberman, D.; Lieberman, M. 1987. Forest tree growth and dynamics at La Selva, Costa Rica (1969-1982). Journal of Tropical Ecology, v.3, p.347-358.
Lima, S.F. de: Carvalho, J.O.P. de. 2000. Estrutura de uma floresta de terra firme na região de Marabá-PA: a posição do mogno em relação às outras espécies da comunidade. Belém: EMBRAPA-CPATU. 5p. (EMBRAPA-CPATU. Comunicado Técnico, 22).

Lopes, J. do C.A. 1993. Demografia e flutuações temporais da regeneração natural após uma exploraçào florestal: Flona Tapajós-PA. Piracicaba; USP. 133p. Dissertação Mestrado.

Lopes, J. do C.A.; Carvalho, J.O.P. de; Silva, J.N.M.; Costa, H.B. da. 1986. Sociabilidade entre 18 espécies comerciais ocorrentes na Floresta Nacional do Tapajos. In: Symposium of the Humid Tropics, 1., 1984, Belém, PA. Proceedings. Belém: EMBRAPA-CPATU. v.2, p. 263-268. (EMBRAPA - CPATU. Documentos, 36).

Manokaran, N.; Kochummen, K.M. 1987. Recruitment, growth and mortality of tree species in a lowland dipterocarp forest in Peninsular Malaysia. Journal of Tropical Ecology, v.3, p.315-330.

Mori, S.A,; Boom, B.M.; Carvalho, A.M. de; Santos, T.S. dos. 1983. Southern Bahian moist forests. The Botanical Review, v.49, p.155-232.

Nicholson, D.I.; Henry, N.B.; Rudder, J. 1990. Reply-disturbance regimes in North Queensland rainforests: a re-evaluation of their relationship to species richness and diversity. Australian Journal of Ecology, v.15, p.245-246.

Nicholson, D.I.; Henry, N.B.; Rudder, J. 1998. Stand changes in north Queensland rainforests. Proceedings of the Ecological Society of Australia, v.15, p.61-80.

Okali, D.U.U.; Ola-Adams, B.A, 1987. Tree populations changes in treated rain forest at Omo Forest Reserve, South-western Nigeria. Journal of Tropical Ecology, v.3, p. 291-313.

Pires, J.M.; Dobzhansky, T.H.; Black, G.A. 1953. An estimate of the number of species of trees in an Amazonian forest community. Botanical Gazette, v.114, p.467- 
477.

Sandel, M.P.; Carvalho, J.O.P. de. 2000. Composição florística e estrutura de uma área de cinco hectares de mata alta sem babaçu na Floresta Nacional do Tapajós. Belém: Embrapa Amazônia Oriental, 15p. (Embrapa Amazônia Oriental, Documentos, 63).

Saxon, E.C. 1990. Disturbance regimes in North Queensland rainforests: a re-evaluation of their relationship to species richness and diversity. Australian Journal of Ecology, v.15, p.,241-244.

Silva, J.N.M. 1989. The behaviour of the tropical rain forest of the Brazilian Amazon after logging. Oxford: University of Oxford. D. Phil. Thesis.

Silva, J.N.M.; Lopes, J. do C.A. 1984. Inventário florestal contínuo em florestas tropicais: a metodologia utilizada pela EMBRAPA-CPATU na Amazônia brasileira. Belém: EMBRAPA-CPATU. 36p. (EMBRAPA-CPATU. Documentos, 33).

Silva, J.N.M; Carvalho, J.O.P. de; Lopes, J. do C.A. 1985. Inventário florestal de uma área experimental na Floresta Nacional do Tapajós. Boletim de Pesquisa Florestal, v.10/11, p.38-110.

Soares, M.H.M.; Carvalho, J.O.P. de. 1999. Diversidade floristica em uma área de 200 hectares de floresta natural no municipio de Moju no Pará. Belém: EMBRAPACPATU. p.110-115. (EMBRAPACPATU. Documentos, 123).

SUDAM (Belém, PA). 1981. Grupamento de espécies tropicais da Amazônia por similaridade de caracteristicas básicas e por utilização. Belém.

Swaine, M.D.; Hall, J.B.; Alexander, I.J. 1987a. Tree population dynamics at Kade, Ghana (1968-1982). Journal of Tropical Ecology, v.3, p.331-345.

Swaine, M.D.; Lieberman, D.; Putz, F.E. 1987b. The dynamics of tree populations in tropical forest: a review. Journal of Tropical Ecology, v.3, p.359-366.

Swaine, M.D.; Whitmore, T.C. 1988. On the definition of ecological species groups in tropical rain forests. Vegetatio, v.75, p.8186.

Synnott, T.J. 1979. A manual of permanet plots procedures for trpical rain forests. Tropical Forestry Papers, v.14.

Texeira, D.E,; Santana, M.A.E.; Souza, M.R. de. 1988. Amazonian timbers for the international market. Brasília: IBDF/ITTO. (ITTO. Technical Series, 1).

Whitmore, T.C. 1984. Tropical rain forests of the Far East, 2.ed. Oxford: Clarendon. $352 \mathrm{p}$.

Whitmore, T.C. 1988. The influence of tree population dynamics on forest species composition. In: Davy, A.; Hutchings, M.J. (eds.) Plant population ecology, Oxford: Blackwell. p.271-291.

Whitmore, T.C. 1989a. Canopy gaps and the two major groups of forest trees. Ecology, v.70 p.536-538.

Whitmore, T.C. 1989b. Changes over twentyone years in the Kolombangara rain forests. Journal of Ecology, v.77, p.469-483.

Whitmore, T.C. 1990. An introduction to tropical rain forests. Oxford: Clarendon. 226p.

\section{Aceito para publicação em 22/04/2002}

